\title{
The Implementations and Challenges of Continuous Assessment in Public Universities of Eastern Ethiopia
}

\author{
Gemechu Abera \\ Asst. Prof., corresponding author, Haramaya University, Ethiopia, \\ gemechu46@yahoo.com
}

\section{Muhammed Kedir}

Asst. Prof., Haramaya University, Ethiopia

Maeregu Beyabeyin

Asst. Prof., Haramaya University, Ethiopia

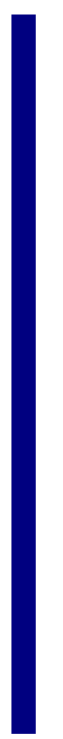

\begin{abstract}
The study was aimed to investigate the implementations and challenges of continuous assessment in selected Public Universities of Eastern Ethiopia. Descriptive survey research design was employed to carry out this study because it is used to describe the characteristics of a given population in a systematic and accurate fashion. Stratified random sampling technique was employed to collect pertinent information from the respondents through questionnaire and observational checklists. To make the interpretation of the findings easier, the researchers used both descriptive and inferential statistics. The first finding was that almost the implementations of continuous assessment in these selected universities were very poor. The second finding was that there was statistically a significant mean difference among these public universities in utilizing and implementing continuous assessment; the third finding was that there was statistically significant mean difference among these sampled respondents in implementing the three domains of educational objectives; the fourth interesting finding was that the implemented continuous assessment type was highly dominated by cognitive, followed by affective and then psychomotor domains respectively. Finally, it was recommended that instructors should implement continuous assessment not only for the sake of evaluating and marking students' result but also for the sake of learning skills and practices.
\end{abstract}

Keywords: implementation, challenge, continuous assessment, assessment, department of psychology, Haramaya University

\section{INTRODUCTION}

Throughout the world, it is apparent that the subject of assessment is becoming more

Citation: Abera, G., Kedir, M., \& Beyabeyin, M. (2017). The Implementations and Challenges of Continuous Assessment in Public Universities of Eastern Ethiopia. International Journal of Instruction, 10(4), 109-128. https://doi.org/10.12973/iji.2017.1047a 
and more central to the whole process of higher education, as it has found ways to assure and enhance the quality of educational provision, with a changed focus on outcomes rather than input. If we want to know what students have learned and how effective the learning process has been, the evidence we primarily turn to is students' work and how it has been assessed. This indicates that assessment of students' learning has recently generated considerable interest in educational circles (Teshome, 2001). This interest has focused on such issues as the extent to which teachers should incorporate and state standards into their teaching and assessment, as well as the degree to which teachers should use traditional tests or alternative assessments. The coverage of classroom assessments begins with an examination of the varied features of the classroom as an assessment context. From the explanation, one can understand that assessment matters to students, the teachers who assess them, the institutions in which they are assessed, the parents, partners, and careers who support them; it matters to the employers who would like to offer them jobs on graduation and to the funders who pay for higher education and want to see the maintenance of standards and values of money (Smith, 1996).

On the other hand, there is a growing mistrust of paper and pencil made examinations globally. They are criticized for their detrimental effects on instruction and students. Eckstein and Noah (1992); Smith (1996) and Adams (1996) pointed to the problems and weaknesses of paper and pencil made assessment in general and paper made tests and examination in particular. These effects include (1) focus on irrelevant concepts that do not impact directly on students' lives; (2) biasness that results from factors such as use of foreign languages, gender bias, and favor of certain ethnic groups; (3)discrimination against other learners who live in poor socio-economic conditions and the less gifted learners who may cause learning problems and lowered self-esteem in learners; (4) unnecessary academic overloading or voluminous factual knowledge provided to students in preparation for examinations; (5) alarming failure rates as a consequence of overloading, biasness and unreliable grading; and (6) superficial, rote learning and negligence of higher order thinking skills such as reasoning, problem solving, imagination and independent inquiry and mismatch between education and job market that results in lack of necessary skills required in the workplace (Abruscado, 2000).

These necessitate institutions of higher education to seek more valid alternative ways of assessing students. It is envisaged that use of continuous assessment practices may provide reliable evidence of the competences that are developed in the prospective labor force for any country. Continuous assessments entail a range of assessment methods designed to take the place of or to supplement paper and pencil tests and examinations (Schwartz \&Webb, 2002). These may involve use of projects, extended essays, portfolios, paper presentations, exhibitions, examinations and tests to assess learners' achievements (Hart, 1994). These days many countries such as Spain, Australia, England and others are applying continuous assessment partly or wholly in their educational system (Heaton, 1990). In addition, Nikko (1995) states that in many countries educators are expressing their interest toward assessments into two different ways. Their interests appear to arise from related, but different educational concerns. First educator recognizes that good instruction requires information about the instruction requires information about the student progress. The second reason for educators' 
interest in continuous assessment is to become fair to the students.

Taking all these into account, the Ethiopian Ministry of Education- MoE (1994) introduced continuous assessment at various levels of educational institutions. The practical task of implementing the new curriculum at school level requires continuous assessment as part of curriculum in general and the instructional process in particular. To realize this, the role of teachers is undeniable. Assessment of student achievements is subjected to several challenging and emerging socio-economic factors worldwide. These challenges hit hard on the quality of assessment practices (Smith \& Maclec, 1994). These dynamics and challenges of education impact on higher education to the extent that the nature of higher education is in a continuing flux. More than twenty-five years ago, Kellaghan and Greaney (1992) indicated that the problem of the unsatisfactory quality of education was not new to Ethiopia. Therefore, assessing the status of the implementation and the challenges of continuous assessment was found to be very crucial in these Public Universities of Eastern Ethiopia by the research groups.

\section{THEORETICAL FRAMEWORK}

Educational assessment provides the necessary feedback we require to maximize the outcomes of educational efforts. The assessment of learners' learning provides objective evidences necessary in the decision-making process in education. As clearly pointed out by Cone and Foster (1991), good assessment resulting in accurate data is the foundation of sound decision making. There is little doubt among educational practitioners about the special value of assessment as a basic condition for effective learning. The major problems of assessment of learners have been in the approaches or methods. There is a large amount of literature on assessment-incorporating behaviourist, cognitive, constructivist and socio-cultural (situative) approaches to education. Much of the literature on assessment focuses on summative assessment but there is also a large body of literature centred on formative feedback and on formative assessment. Much of the literature, although very valuable, is heavy going for a teacher starting out in higher education. The intention of this idea is to utilize the literature in order to deconstruct the theoretical and philosophical aspects of formative feedback and formative assessment and in so doing consider the pragmatics of using formative feedback and formative assessment in the teaching practice to enable teachers to enhance the opportunities for their students to learn ( Alastair, 2008) .

Continuous assessment would alter the learning environment in higher education and provide positive student-learning opportunities, encourage dialogue between teachers and students. It also enhances the student-learning experience, provide motivation for students by moving toward a formative assessment ethics and allow students to take responsibility and ownership for their learning and education (Alastair, 2008). There are a number of common themes that will be addressed in assessment in higher learning which includes: (1) the involvement and engagement of students in the feedback process-one might think this is fairly obvious, but is actually quite tricky to achieve;(2) explaining to students how formative assessment activities are contributing to their learning; (3) providing timely and constructive feedback on assessment activities; (4) 
ensuring equity and equality in all formative activities taking into account the diverse student population.

\section{The purpose of assessment}

A review of the literature on assessment suggests a range of functions of assessment including: (1) to inform an overall judgment of achievement, which may be needed for reporting and review. (2) As a means of giving feedback to students-for example Pelligrino et al. (2001) suggest that an assessment is a tool designed to observe students' behaviour and produce data that can be used to draw reasonable inferences about students' knowledge. (3) To provide feedback to academic staff by using assessment as a measurement of the success of learning and teaching, for example William (2000) suggests that an aspect of summative assessment is to provide information with which teachers, educational administrators and politicians can be held accountable to the wider public; an argument supported by Pelligrino et al. (2001) suggesting that assessments serve a vital role in providing information to help students, parents, teachers, administrators and policy makers to reach decisions. (4) The accountability of academic staff, for example in the argument put forward by Black (1999) that results of assessment 'may also be used for judging the achievement of individual teachers or of schools as a whole. (5) A means of monitoring standards, as argued in William (2000), and the standard can be measured at individual, module, programme, school, institution, sector, national or international levels. (6) As a means of enabling student learning during assessment activities Rowntree (1987) although suggests that this might be an instrument of coercion getting students to participate in activities that they would not normally choose to take part in. (7) Preparation for life Falchikov (2005), traditionally seen as an input to employment or career advancement, but he argues that more important skills such as collaboration and sharing can be developed through assessment.

All these factors contributed to an inordinate amount of stress on academic staff when dealing with assessment. It is little wonder that people feel pressure when they are engaging in assessment-both staff and students (Gemechu, 2013). The ranges of issues associated with assessment also mean that it is an item which is often under scrutiny from institutional management, school management, external examiners and other external bodies.

\section{The process of assessing learning: what to assess?}

Closely connected with the question 'what to assess?' is the issue of where to seek evidence of learning? Learning is likely to be found (and so assessed) in the continuous relationship between the student and the practice teacher / tutor, between the student and the practice agency, and between the student and the educational institution (Cree et al. 1998). It will therefore be evidenced in supervision and tutorial discussions, in student groups and classrooms and in the preparation of learning tasks for supervision and tutorials. Learning may also be demonstrated in a whole range of assessed and nonassessed written work: in practice studies and reports, dissertations, process recordings, learning logs and perhaps even in examination papers, when a student makes useful connections between theory and practice or past and present experience or learning. The 
issue here is not the assessment tool per se, but the way the assessment method is used, and the kind of question that is asked. Learning will also be found in practice with service users when a student purposefully and creatively draws on his/her experiences of life or work (Evans, 1990). These issues have been missed in the Ethiopian education in general and its higher institution in particular.

Rowntree (1987), counsels against prescribing too early what are to be valued in a student's work. He points out that to do so risk 'closing our eyes against evidence of valuable student learning that happens to lie outside our prior specifications. Research into assessment demonstrates that students learn best through an assessment design which is 'step-up' in character, building on basic knowledge and skills into more and more complex learning (Bryce and McCall, 1990). Because of the nature of transfer of learning, it is difficult to envisage a simple 'step-up' approach to its assessment. Students have very different starting-points in terms of their ability to transfer learning, and this makes any generalized model difficult to sustain. Nevertheless, it seems likely that the assessment of learning will be enhanced by an exploration at the beginning of training of a student's existing knowledge, skills and experience and the ways the student learns most readily. This can then be the starting-point for a shared discussion that takes place at regular intervals throughout the course of training.

\section{Research aim}

The purpose of this study was to investigate the implementations and challenges of continuous assessment in selected Public Universities of Eastern Ethiopia. Specifically, the study was intended to:

(i) assess the extent to which continuous assessments were utilized in the public Universities of Eastern Ethiopia

(ii) identify some techniques of continuous assessment implemented in these selected public universities to evaluate students' learning

(iii) investigate the challenge that hinders the implementation of continuous assessment in the public Universities of Eastern Ethiopia

(iv) pinpoint the alternative strategies that have been made so as to solve the challenges of implementing continuous assessment in these Public Universities of Eastern Ethiopia

(v) make necessary recommendations on the basis of the findings of the study.

\section{METHOD}

Descriptive survey research design was employed in carrying out this study. With its many applications, survey research is a popular design in education. Survey research designs are procedures in quantitative research in which investigators administer a survey to a sample or to the entire population of people to describe the attitudes, opinions, behaviours, or characteristics of the population (Cress well, 2012). In this procedure, survey researchers collect quantitative, numbered data using questionnaires or observational checklists and statistically analyse the data to describe trends about responses to questions and to test research questions or hypotheses. They also interpret the meaning of the data by relating results of the statistical test back to past research 
studies. Survey designs differ from experimental research in that they do not involve a treatment given to participants by the researcher. Because survey researchers do not experimentally manipulate the conditions, they cannot explain cause and effect as well as experimental researchers can. So, the implementation and the challenges of continuous assessment in Public Universities of Eastern Ethiopia were surveyed and the data collected were subjected to both quantitative and qualitative analysis.

\section{Study samples}

The samples used for this study consisted of 580 students out of the total target population of 1,358 students who have been attending their undergraduate studies in three different universities (Dire Dewa, Haramaya and Jigjiga) sampled by using stratified random sampling technique. This is because firstly, there were different subdivisions in the targeted population which are important to be considered; secondly, there were also variations in population sizes of different strata in this case (universities, colleges, and departments) of the populations. To take these 580 students, the researchers used systematic random sampling through calculating the intervals $\left(\mathrm{K}^{\text {th }}\right.$ value) at which the sample has been selected after alphabetically arranging the target population under the study. The returned rate of the questionnaire was $97.76 \%$ which was 567 students who were fully responded the items so that all the analyses were made on these 567 respondents.

The researchers used questionnaire that contain four set of questions. The first set items contained items that talk about the status of the implementations of continuous assessment; the second part of it was about the domains of educational objectives; the third part was also talking about the techniques of continuous assessment employed, and the fourth part of the questionnaire contained the challenges and strategies about the implementations of continuous assessment to test the research questions and hypotheses. A pilot study was conducted on 30 students who represented the population character but not the sample to check the reliability through using Crookback Alpha value which was found to be $(\alpha=0.87)$. Accordingly, the researchers were able to decide the characteristics of the items that need to be adjusted or remained or to change some technical words or phrases that seemed to be too technical for these respondents. Besides, the validity, particularly the content validity was checked by research groups to check the extent to which what each item was expected to measure. Moreover, observational checklists were prepared for physically observed assessment related issues to departments /colleges / institutes/ faculties to be filled the checklists on the implementation and the challenges of continuous assessment which were mainly used for triangulation.

To make the interpretation descriptively easier, the researchers used descriptive statistics (percentages, means, and standard deviation) to describe the characteristics of the respondents. Furthermore, inferential statistics- (1) one way ANOVA was employed to see the significance mean differences among the three public universities' respondents and (2) Kruskal Wallis Test was also used to test whether there was a significant mean rank difference among the three public universities' respondents response even though it drops the assumption that the populations are normally distributed. This result was 
significant at $\alpha=0.05$ level. The data obtained from the respondents were analysed using the Statistical Package for the Social Sciences (SPSS version 16). The mean score (M) was used to see the level of the degree of agreement of respondents on the implementation and the challenges of continuous assessment in the study area. Accordingly, if the computed mean score $(\mathrm{M})=1.00-1.50$, it is strongly disagree/never; if $\mathrm{M}=1.50-2.50$, it is disagree / rarely; if $\mathrm{M}=2.50-3.50$, it is undecided/ occasionally, if $\mathrm{M}=3.50-4.50$, it is agree/ frequently, and if $\mathrm{M}=4.50-5.00$, it is strongly agree/ very frequently (Anderson, 2003).

\section{FINDINGS AND DISCUSSIONS}

This part presents the analysis and interpretation of the main idea. To this end, both quantitative and qualitative data gathered from questionnaire and observational checklists were subjected to both quantitative and qualitative analyses. Questionnaire was distributed to 580 respondents (in- the three universities) and 567 (99.76\%) copies were returned back.

Table1

The status of implementations of continuous assessment $(n=567, p<0.05)$

\begin{tabular}{|c|c|c|c|c|c|c|c|c|c|}
\hline \multicolumn{5}{|c|}{ Descriptive Analysis } & \multicolumn{5}{|c|}{ ummary of ANOVA Analysis } \\
\hline No & & Freq & Percent & SV & SS & df & MS & $\mathrm{F}$ & Sig. \\
\hline 1 & Never & 143 & 25.2 & Between Groups & 30.92 & 2 & 15.459 & 14.5 & \\
\hline 2 & Rarely & 221 & 39.0 & Within Groups & 600.33 & 564 & 1.064 & & 0.00 \\
\hline 3 & Occasionally & 136 & 24.0 & Total & 631.25 & 566 & & & \\
\hline 4 & Frequently & 42 & 7.4 & & & & & & \\
\hline 5 & $\begin{array}{l}\text { Very } \\
\text { frequently }\end{array}$ & 25 & 4.4 & & & & & & \\
\hline
\end{tabular}

As it can be observed from the table1, the majorities $(364,64.2 \%)$ of the respondents responded that their instructors implemented continuous assessment rarely and never; $(67,11.8 \%)$ of them responded that their instructors implemented continuous assessment frequently and very frequently whereas the rest $(136,24.0 \%)$ of them responded that their instructors implemented CA occasionally. Furthermore, the computed F ratio at $\alpha=$ $0.05, \mathrm{~F}(2,566)=14.5$ which exceeds the critical region at $\alpha=0.05, \mathrm{~F}(2,566)=3.09$. Hence, it was concluded that there was statistically significant mean difference among the respondents in utilizing and implementing continuous assessment, $\mathrm{F}(2,566)=14.5$, $\mathrm{p}<0.05$, one tailed. In support of this finding, Hart (1994) indicated that continuous assessments entail a range of assessment methods designed to take the place of or to supplement paper and pencil tests and examinations that may involve use of projects, extended essays, portfolios, paper presentations, exhibitions, examinations and tests to assess learners' achievements on regular bases. Additionally, the observational checklist evidenced that most of these respondents under the study did not utilize and implement continuous assessment in their respected universities. 
Table 2

The domains of educational objectives $(n=567, \mathrm{p}<.05$

\begin{tabular}{|c|c|c|c|c|c|c|c|c|}
\hline \multicolumn{4}{|c|}{ Descriptive Analysis } & \multicolumn{5}{|c|}{ Summary of ANOVA Analysis } \\
\hline $\begin{array}{c}\text { Domains of } \\
\text { educational objectives }\end{array}$ & Freq & Percent & SV & SS & df & MS & $\mathrm{F}$ & Sig. \\
\hline Cognitive domain & 268 & 47.3 & Between Groups & 119.30 & 2 & 59.65 & 19.70 & 0.00 \\
\hline Affective domain & 86 & 15.2 & Within Groups & 1707.63 & 564 & 3.03 & & \\
\hline Psychomotor domain & 74 & 13.0 & Total & 1826.94 & 566 & & & \\
\hline Cognitive and Affective & 41 & 7.2 & & & & & & \\
\hline $\begin{array}{l}\text { Cognitive and Psycho- } \\
\text { motor }\end{array}$ & 18 & 3.2 & & & & & & \\
\hline $\begin{array}{l}\text { Cognitive, Affective and } \\
\text { Psychomotor motor }\end{array}$ & 80 & 14.1 & & & & & & \\
\hline
\end{tabular}

As it can be observed from table2, the majorities $(268,47.3 \%)$ of the respondents responded that their instructors dominantly used the cognitive domain of learning while assessing their students; $(86,15.2 \%)$ of them responded their instructors used affective domain while assessing their students; $(74,13.0 \%)$ of the respondents responded that their instructors used the psychomotor domain. Moreover, $(41,7.2 \%)$ of the respondents responded their instructors used the cognitive domain and affective domain which were not as such satisfactory whereas $(18,3.2 \%)$ of them responded that their instructors were the cognitive and psychomotor which were least implemented domain of educational objectives in these public universities.

However, $(80,14.1 \%)$ of the respondents responded that their instructors used the three domains of educational objectives in teaching-learning processes. From this one can understand that the degrees of implementation of CA in these Public universities were not balancing the three domains of educational objectives. Furthermore, the computed $\mathrm{F}$ ratio at $\alpha=0.05, \mathrm{~F}(2,564)=19.70$ which exceeds the critical region of at $\alpha=0.05, \mathrm{~F}$ $(2,564)=3.09$. Consequently, it was concluded that there was statistically significant mean differences among the respondents in implementing the three domains of educational objectives in assessing students' learning, $F(2,564)=19.70, p<0.05$, one tailed. In support of this finding, Boud (1998) suggests that assessment methods and requirements probably have a greater influence on how and what students learn in comprehensive domains of educational objectives namely cognitive, psychomotor and affective domains than other single domain. This problem is perpetuating despite the worldwide call to move away from traditional cognitive domain ways of assessing students (Smith and Malec, 1995). Additionally, the observational checklist evidenced that most of these respondents under the study were not utilized the three domains of educational objectives equally by their instructors in assessing students' learning. 
Table3

Techniques of continuous assessment employed $(\mathrm{n}=567, \mathrm{p}<.05)$

\begin{tabular}{|c|c|c|c|c|c|c|c|c|c|}
\hline Descriptive $A$ & Analysi & & & Sum & mary of & $\overline{\text { ANOVA } A}$ & nalysis & & \\
\hline $\begin{array}{l}\text { Techniques of } \\
\text { Assessment }\end{array}$ & M & SD & SV & SS & df & & MS & $\mathbf{F}$ & Sig. \\
\hline Portfolios & & & Between Groups & 0.97 & 2 & 0.48 & 0.67 & & 0.51 \\
\hline & 1.72 & 0.85 & Within Groups & 409.01 & 564 & 0.73 & & & \\
\hline & & & Total & 409.97 & 566 & & & & \\
\hline Demonstrations & & & Between Groups & 11.61 & 2 & 5.807 & 8.82 & & 0.00 \\
\hline & 1.87 & 0.82 & Within Groups & 371.24 & 564 & 0.66 & & & \\
\hline & & & Total & 382.86 & 566 & & & & \\
\hline Experiment & & & Between Groups & 118.99 & 2 & 59.50 & 71.56 & & 0.00 \\
\hline & 2.18 & 1.02 & Within Groups & 468.72 & 564 & 0.83 & & & \\
\hline & & & Total & 587.71 & 566 & & & & \\
\hline Attendance & & & Between Groups & 8.38 & 2 & 4.19 & 5.37 & & 0.05 \\
\hline & 2.24 & 0.09 & Within Groups & 440.45 & 564 & 0.71 & & & \\
\hline & & & Total & & & & & & \\
\hline Project Works & & & Between Groups & 86.03 & 2 & 43.01 & 57.06 & 0.00 & \\
\hline & 2.36 & 0.95 & Within Groups & 425.13 & 564 & 0.75 & & & \\
\hline & & & Total & 511.16 & 566 & & & & \\
\hline Field work & & & Between Groups & 119.88 & 2 & 59.94 & 77.72 & 0.00 & \\
\hline & 2.57 & 0.99 & Within Groups & 434.96 & 564 & 0.77 & & & \\
\hline & & & Total & 554.86 & 566 & & & & \\
\hline Extended Essay & & & Between Groups & 434.545 & 2 & 217.27 & 257.00 & 0.00 & \\
\hline & 2.74 & 1.27 & Within Groups & 476.82 & 564 & 0.85 & & & \\
\hline & & & Total & 911.37 & 566 & & & & \\
\hline Group works & & & Between Groups & 56.10 & 2 & 28.05 & 27.07 & 0.00 & \\
\hline & 3.11 & 1.06 & Within Groups & 584.34 & 564 & 1.04 & & & \\
\hline & & & Total & 640.44 & 566 & & & & \\
\hline Individual works & & & Between Groups & 309.48 & 2 & 154.74 & 167.20 & 0.00 & \\
\hline & 3.52 & 1.21 & Within Groups & 521.95 & 564 & 0.93 & & & \\
\hline & & & Total & 831.43 & 566 & & & & \\
\hline Paper-pencil & 40 & 062 & Between Groups & 1.35 & 2 & 0.68 & 1.71 & 0.18 & \\
\hline & 4.27 & & Within Groups & 222.05 & 564 & 60.39 & & & \\
\hline & & & Total & 223.40 & 566 & & & & \\
\hline
\end{tabular}

From the table3, it was clearly indicated that the computed mean score of the respondents were $4.29,3.52,3.11,2.74,2.57,2.36,2.24,2.18,1.87$ and 1.72 respectively were paper-pencil made exam, individual works, group works, extended essay, field work, project, attendance, experiment, demonstrations and portfolio from the most frequently used to the least frequently used techniques of assessment. From this 
analysis it was found that paper-pencil made exam was the most dominantly used assessment techniques whereas portfolio was the least implemented one in assessing students' learning. However, the computed standard deviations respectively were 0.63 , $1.21,1.06,0.99,0.95,0.89,1.02,0.82$ and 0.85 which showed us that there was a little dispersion among the respondents in the three public universities.

Furthermore, the computed $\mathrm{F}$ ratio for paper-pencil made exam and portfolio at $\alpha=$ $0.05, \mathrm{~F}(2,564)=1.71$ and $\mathrm{F}(2,564)=0.67$ which were much less than the critical region at $\alpha=0.05, \mathrm{~F}(2,564)=3.09$. Hence, it was concluded that there were no statistically significant mean differences among respondents in utilizing paper-pencil made exam and portfolio as techniques of continuous assessment in teaching-learning processes, $F(2,564)=1.71$ and $F(2,564)=0.67 p>0.05$, one tailed. In support of this idea, Gemechu (2013) strongly recommends that assessment of students' learning should occur in different ways and continuously so as to match the differing ways in which learning is manifested rather than using solely paper- pencil made exams. Additionally, the observational checklist evidenced that most of the respondents were observed that their instructors were not utilized in all these techniques of assessment in assessing students' learning.

On the other hand, the computed $\mathrm{F}$ ratio for the rest techniques of continuous assessment (individual works, group works, extended essay, field work, project, attendance, experiment and demonstrations at $\alpha=0.05$, were found to be $F(2,564)=167.2, \mathrm{~F}$ $(2,564)=27.07, \mathrm{~F}(2,564)=257.00, \mathrm{~F}(2,564)=77.72, \mathrm{~F}(2,564)=56.06, \mathrm{~F}(2,564)=$ $5.37, F(2,564)=71.56$ and $F(2,564)=8.82$ which respectively were much more than the critical region at $F(2,564)=3.09$. As a result, it was concluded that there were statistically significant mean differences among the respondents in utilizing these techniques of continuous assessment in assessing students' learning, $\mathrm{F}(2,564)=167.2$, $\mathrm{F}(2,564)=27.07, \mathrm{~F}(2,564)=257.00, \mathrm{~F}(2,564)=77.72, \mathrm{~F}(2,564)=56.06, \mathrm{~F}(2,564)=$ $5.37, \mathrm{~F}(2,564)=71.56$ and $\mathrm{F}(2,564)=8.82, \mathrm{p}<0.05$, one tailed. In support of this idea, Gemechu (2013) strongly recommends that assessment of students should occur in different ways and continuously so as to match the differing ways in which learning is manifested. Additionally, the observational checklist evidenced that most of the respondents were responded that their instructors were not adequately utilizing these techniques of continuous assessment in assessing students' learning.

\section{The challenges of continuous assessment}

The researchers would not attempt to cover all the challenges that could be associated with continuous assessment practice in all public higher education in Eastern Ethiopia. Rather they would mainly concentrate on the challenges of continuous assessment that could be associated with the learners. The problems of continuous assessment that could be associated with the learners include: plagiarisms, lack of feedback, large class size, shortage of time, lack of (facilities, awareness, opportunities, assessment tactics, assessment specification, theory- practice, authentic assessment policies, and portfolio design) were the main challenges that we would like to discuss in this paper. 


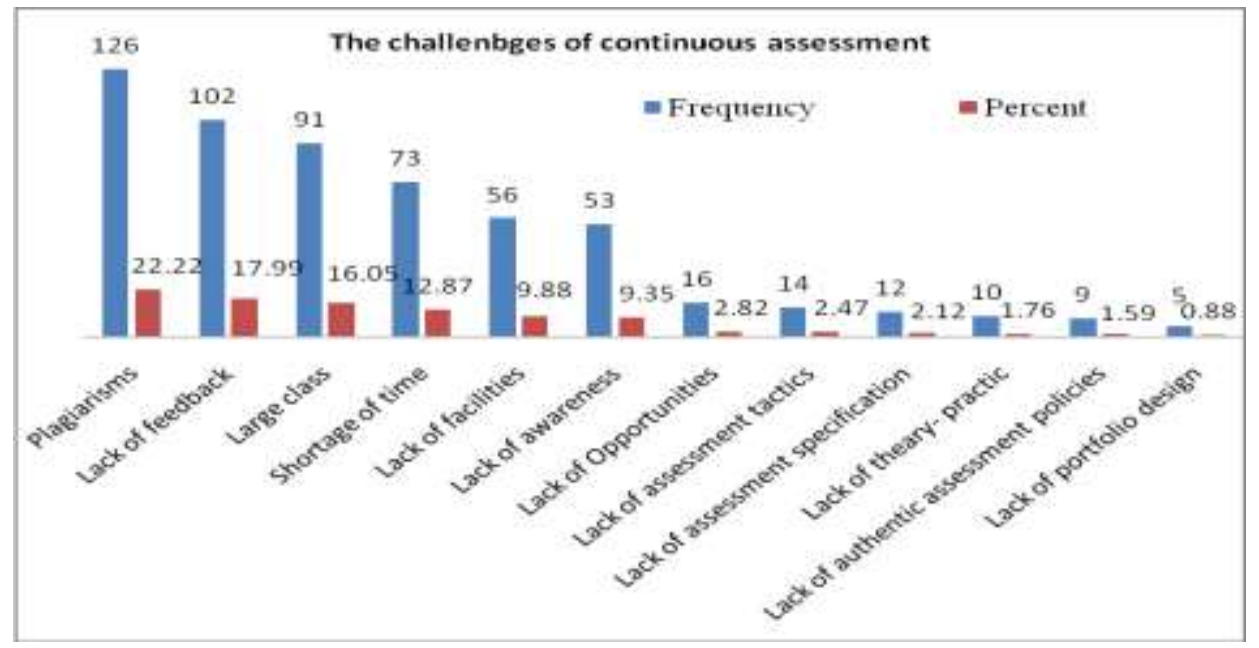

Fig 1

The challenges of continuous assessment

As it can be revealed from the figure1, $(126,22.22 \%),(102,17.99 \%),(91,16.05 \%)$, $(73,12.87 \%),(56,9.88 \%),(53,9.35 \%),(16,2.82 \%),(14,2.47 \%),(12,2.12 \%)$, $(10,1.76 \%),(9,1.59 \%)$ and $(5,0.88 \%)$ of the respondents respectively responded that plagiarisms, lack of feedback, large class size, shortage of time, lack of (facilities, awareness, opportunities, assessment tactics, assessment specification, theory- practice, authentic assessment policies, and portfolio design) ranged from the most challenge (plagiarisms) to the least challenge (lack of portfolio design). In support of this finding, Cowan (2003) suggests that feedback needs to be provided 'within minutes' of completing a task in order to be the most effective. Moreover, Brown et al. (1998) highlight that feedback is at its most effective when it is timely, relevant and meaningful. Other research undertaken by Tuckman (1999) suggests a link between providing students with regular feedback on academic performance and an improvement in subsequent academic performance. Used interchangeably, overcrowded or large classrooms are those where the student-teacher ratios (STR) exceed 40:1(UNESCO, 2007). Such classroom conditions are particularly acute in the developing world where class sizes often swell up and beyond 100 students. All these challenges contributed to an inordinate amount of stress on academic staff when dealing with assessment. It is little wonder that people feel pressure when they are engaging in assessment-both staff and students. The rationale for considering feedback in the context of higher education is that appropriate use of feedback can enhance student learning. If we assume that providing opportunities for learning is the key function of higher education then interventions, such as feedback, contribute to student learning. Pellegrino et al. (2001) suggest that 'learning is a process of continuously modifying knowledge and skills' and that feedback is essential to 'guide, test challenge or redirect the learner's thinking'. Stefani (1998) argues that supportive feedback, both oral and written, when it is given in a supportive and constructive way is a vital element for student learning. 
Table 4

The challenges of continuous assessment $(\mathrm{ni}=567, \mathrm{p}<.05)$

\begin{tabular}{ccccc}
\hline & Kruskal-Wallis Rank order Test & & \\
Universities & Mean rank & df & $\chi^{2}$ & Sig. \\
\hline HU & 285.21 & 2 & 0.033 & 0.984 \\
DDU & 284.08 & & & \\
JJU & 282.23 & & & \\
\hline
\end{tabular}

As it can be observed from table 4, the ranks of the three independent samples of the three higher learning public universities were identified as Haramaya, Dire Dawa and Jigjiga Universities from the first to the third, respectively. However, the computed Kruskal-Wallis Test was found as $\alpha=0.05, \chi^{2}(2)=0.033$, which is much less than the critical region at $\alpha=0.05, \chi^{2}(2)=5.59$. As a result, it was concluded that there was no statistically significant mean rank difference among respondents on the challenges in implementing continuous assessment, $\chi^{2}=0.033(2, \mathrm{n}=567), \mathrm{p}>0.05$. This means that the data did not provide sufficient evidence to conclude that there are significant differences among the three universities on these challenges. Additionally, the observational checklist evidenced that most of these respondents under the study were encountered very serious challenges in implementing continuous assessment in teachinglearning processes.

\section{Alternative strategies}

The alternatives strategies in building and implementing continuous assessment in these study include: communicating with students about feedback, engaging students in learning, maximizing student motivation and drives to change, promoting synergy between motivation and active learning, minimizing resistance to change, convincing students to change their approach to assessments, providing incentive for change, increasing effort required to change, improving teachers and students expectations to change, avoiding imposition of change on teachers, institutional support and convincing teachers in the institution for change were the main alternative strategies in intervening those challenge of implementing continuous assessment that we would like to discuss in this paper. 


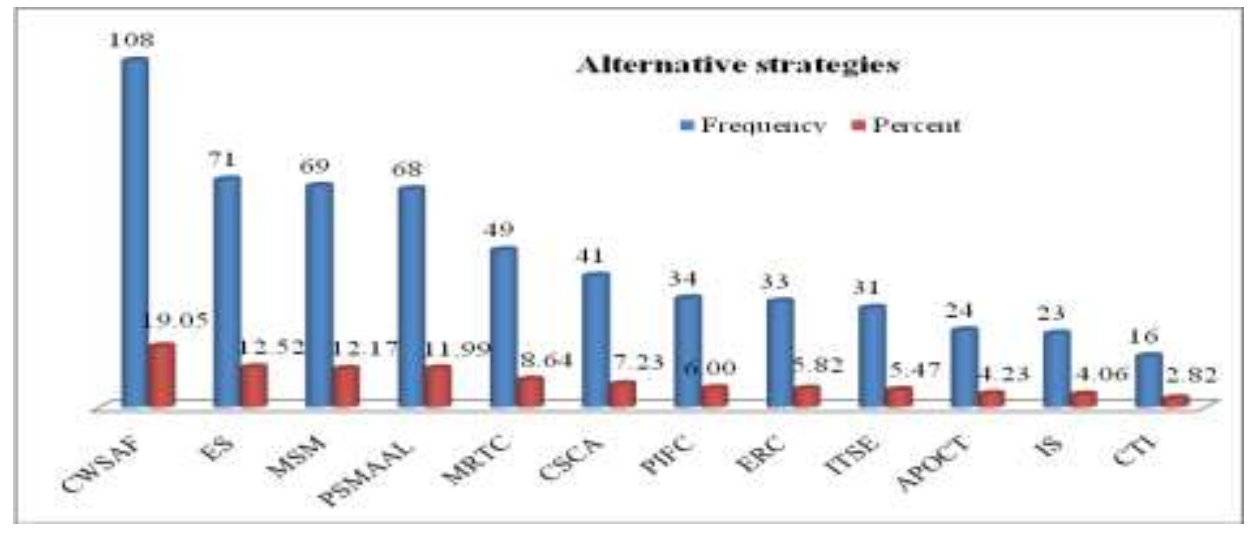

Fig.2

Alternative strategies of continuous assessment

As it can be seen from the figure 2, (108, 19.05\%), (71, 12.52\%), (69, 12.17\%), (68, $11.99 \%),(49,8.64 \%),(41,7.23 \%),(34,6.00 \%),(33,5.82 \%),(31,5.41 \%),(24,4.23 \%)$, $(23,4.06 \%)$ and $(2.82 \%$ of the respondents responded that communicating with students on feedback (CWSAF), engaging students in learning (ES), maximizing student motivation and drives to change (MSM), promoting synergy between motivation and active learning (PSMAAL), minimizing resistance to change (MRTC), convincing students to change their approach to assessments (CSCA), providing incentive for change (PICFC), increasing effort required to change (ERC), improving students expectations to change (ITSE), avoiding imposition of change on teachers (APOCT), institutional support (IS) and convincing teachers in the institution for change (CTI) ranged from the most alternative strategies (communicating with students on feedback) to the least alternatives (convincing teachers in the institution for change) to solve the challenges of implementing continuous assessment.

Even though giving feedback takes time, giving constructive and developmental feedback takes more time - there is no way of avoiding this situation. Perhaps the most constructive, and the potentially biggest time saving techniques, are getting students to participate in peer feedback and self-assessment-leading to self-reflection. In support of this finding, McDonald and Boud (2003), indicates that encouraging students to participate in self-assessment and engage in reflecting on their own learning goals is highly effective in enhancing learning and achievement. Students don't necessarily engage in activities the way teachers expect them to and will act in situations according to the way they see or value the situation. Students in higher education have a wide range of motivations and a variety of drives. In order for students to learn effectively, they need to be motivated to learn. Brown et al.'s (1998) text motivating students is a good starting point. If continuous assessment and formative feedback are to be successful learning tools, then there is a need to appreciate that formative assessment doesn't solely depend on the learning activity and the resultant feedback (Gemechu, 2013). 
Table5

Alternative Stratégies $\left(\mathrm{n}_{\mathrm{i}}=567, \mathrm{p}<.0 .05\right)$

\begin{tabular}{cccccc}
\hline \multicolumn{7}{c}{ Kruskal- Wallis- Test statistics } & & & \\
No & Universities & Mean Rank & df & $\chi 2$ & Sig. \\
\hline 1 & HU & 298.90 & 2 & 9.69 & 0.008 \\
2 & DDU & 251.00 & & & \\
3 & JJU & 295.92 & & & \\
\hline
\end{tabular}

As it can be seen from table 5, the ranks of the three independent higher learning public universities were from HU, JJU and DDU from the first to the third respectively. Moreover, the computed Kruskal-Wallis Test was found as $\alpha=0.05, \chi^{2}(2)=9.69$, which is greater than the critical region at $\alpha=0.05, \chi^{2}(2)=5.59$. Therefore, it was concluded that there was statistically significant mean difference among respondents on the alternative strategies to overcome and intervene the challenges of continuous assessment, $\chi^{2}=9.69(2, \mathrm{~N}=567), \mathrm{p}<0.05$. Additionally, the observational checklist evidenced that most of the respondents nominated that the alternative strategies to overcome the challenges in implementing continuous assessment in teaching-learning processes were very different.

\section{CONCLUSION}

Based on the result and discussions parts, the researchers draw the following conclusions:

- From what have been summarized so far, one can conclude that the majorities (rarely + never $=364,64.2 \%$ ) of the respondents responded that their instructors implemented continuous assessment either rarely or never, $(67,11.8 \%)$ of them responded that their instructors implemented continuous assessment either frequently or very frequently whereas the rest $(136,24.0 \%)$ of them responded that their instructors implemented continuous assessment occasionally.

- From one way analysis of variance, it was concluded that there were statistically significant mean differences among the respondents in these public universities in utilizing continuous assessment. This indicates that almost the implementation of continuous assessment in these selected universities was very poor. It can also be concluded that there were statistically significant mean differences among the respondents in implementing the three domains of educational objectives in assessing students' learning as required. From this one can conclude that the degree of implementation of CA in these public universities were not as satisfactory as expected

- From the summary part, it was possible to conclude that respondents who responded that continuous assessments implemented very frequently were $(174,30.6 \%)$. However, the majorities of the respondents $(393,69.3 \%)$ responded that continuous assessments were not implemented very frequently but it was implemented frequently, occasionally, rarely or never. Besides, it can be concluded that there was statistically significant mean difference among these sampled respondents who responded that continuous assessment 
was very frequently implemented in these public universities in teaching-learning processes , $\mathrm{F}(2,173)=50.94, \mathrm{p}<0.05$, one tailed. From this one can conclude that the degree of implementation of $\mathrm{CA}$ in these public universities were not as such satisfactory as expected.

- As far as the implementation of the techniques of continuous assessment were concerned, it was concluded that paper-pencil made exam, individual works, group works, extended essay and field works ranked from most frequently used to the least frequently used techniques. From this, one can conclude that, still the techniques of continuous assessment were more traditional and were not as such in engaging learners as a means of self learning and self assessing. However, there were statistically significant mean differences among the respondents in implementing demonstration, experiment, attendances and project works as techniques of continuous assessment in assessing students' learning. From these data one can conclude that these techniques of continuous assessment were not used as expected in these universities.

- Moreover, from Kruskal Wallis Test, it was concluded that there was no statistically significant mean rank differences among the respondents as far as the challenges and implementations of continuous assessment were concerned. From this, one can conclude that instructors lacked these skills or careless about students' assessment and engagement in the subject they have been delivering.

\section{RECOMMENDATION}

On the bases of the conclusions drawn from the above data, the researchers would like to forward the following recommendations.

-The quality of education and transfer of knowledge, therefore, were, are and will be affected as a result of lack of implementing appropriate continuous assessment. So, these issues need special attention and follow up to solve these problems. Otherwise, the quality of education, curriculum and the kind of graduate from these universities will be affected in general and the country in particular.

-Assessment that did not keep and balance the three domains of educational objectives would be affecting graduates at any educational levels. From these realities, our graduates may lack of focus on relevant concepts that impact directly on their lives; unnecessary academic overloading or voluminous, factual knowledge provided to students in preparation for examinations; alarming failure rates as a consequence of overloading, biasness and unreliable grating; superficial, rote learning and negligence of higher order thinking skills such as reasoning, problem solving, imagination and independent inquiry and mismatch between education and job market that results in lack of necessary skills required in the workplace. Therefore, higher learning institutions' instructors need to observe the learners more keenly to assess their cognitive, affective and psychomotor outcomes very frequently through recording kept on the learners. Otherwise, our graduate may also lose balance of general knowledge, values and skills.

-Teachers needed to be trained on project undertaking and project marking and they; therefore, should not concentrate mainly on home take assignment. This indicates that 
there is no attention has been given to project work, portfolio, experimenting, demonstration, field work and extensive essay which are the most important learning medium that allows students to take active part in learning. Teachers should identify these techniques by their natures that lead learners to greater learning.

-To overcome the challenge of assessments, instructors should be reinforced so as to provide students with extensive written advice on referencing and citation, only to see plagiarism ignored. A useful activity, particularly with students at the beginning of a programme is to bring to a session a wide range of different types of reading materials: books, edited books, journals, and professional magazines, material from the web, reference books and newspaper. Instructors had better provide the students with a referencing guide in the required style of the department or discipline (Harvard or numerical, APA, HU's research writing guide lines).

-Feedback needs be provided by the subject instructors to make specific and sufficient comment and suggestions on strengths, areas for development and strategies for improvement. A key principle of feedback is that it will usefully inform the student about the ways to improve their performance, or feed forward comment on a specific strength acts as advice for the future because it is telling the student to use that particular strategy in future assessments. Likewise, general or obscure criticisms will not be useful. Therefore, instructors must give specific examples from the script of positive or weak sections.

-The shortage of time that was identified in these public universities was especially at the beginning of the academic year of the first and second semesters. These in turn affect the efficiency and the effectiveness of the time budget that have already been allotted to each course. Therefore, teachers should be advised that they should use the day one class one (DOCO) principles that has been used in Haramaya University as a model to solve such problems.

- Lack of facilities should be considered by subject teachers that they had better make students use locally available materials as much as they could. Otherwise, it is obvious that some materials and chemicals related to laboratory issues may not easily available to all students in a college or departments. Therefore, teachers had better use those chemicals that were rare and uneconomical ones only for demonstrations purpose as a sample rather than using or storing them.

While it is true that individual universities, faculties, colleges, schools and departments should be responsible for the particular group of students they are teaching; each academic staff found in these institutions ought to be practice the principle that they also share responsibility for student learning as a whole. What one staff member does in a particular class can affect how students learn in other classes. Consequently, universities faculties, colleges, schools and departments should make collaboration with one another on issues of assessment that can be necessary to ensure the developmental and coherent nature of the curriculum. 


\section{REFERENCES}

Abruscado, J. (2000). Teaching children: A discovery approach. New York: Allyn and Bacon.

Adams, L. D. (1996). Teachers' views on assessment practices in teacher education andschool reform: International yearbook on teacher education. 1996 Conference Proceedings. Vol. II. ICET 1997.

Alastair, I. (2008). Enhancing learning through formative assessment and feedback. London: Routledge.

Black, P. (1999). 'Assessment learning theories and testing systems'. In P. Murphy (Ed). Learners, Learning and Assessment, London, Paul Chapman Publishing, 118-134.

Boud, D. (1998). The role of self-assessment in student grading. Assessment and Evaluation in Higher Education, 14(1), 20-30.

Brown, S., Armstrong, S., \& Thompson, G. (Ed). (1998). Motivatin students. London: Kogan Page.

Bryce, J., \& McCall, D. (1990). The technological transformation of leisure. Social Science Computer Review, 19, 7-16.

Cone, K., \& Faster, L. (1991). Teacher-made assessments: How to connect curriculum, instruction, and student learning. Larchmont, NY: Eye On Education.

Cowan L. (2003). Teacher-made assessments: How to connect curriculum, instruction, and student learning. NY: Eye on Education.

Cree, R. G., Marsh, H. W., \& Debus, R. L. (1998) 'Effects of internally focused feedback on the enhancement of the academic self-concept'. Journal of Educational Psychology, 83(1), 17-27.

Eckstein, K., \& Noahm, K. (1992). How to assess vocational curriculum. London: Kogan Page.

Falchikov, N. (2005). Improving assessment through student involvement: practicalsolutions for aiding learning in higher and further education. London: Routledge Farmer.

Gemechu, A. (2013). Teachers' perceptions in teaching large class sizes in Eastern Ethiopian higher learning institutions, Journal of Education and Practices.5(4),76-75.

Hart, D. (1994). Authentic Assessment. New Jersey: Dale Seymour Publications.

Heaton, J. L. (1990). Large-scale assessment in support of school reform: Lessons in the search for alternative measures. International Journal of Educational Research, 27, 395-413.

Kellaghan, T. \& Greaney, V. (1992). Using examinations to improve education. Kentucky department of education: Early learning program. Kentucky Primary 
Assessment. September 1995.

McDonald, B., \& Boud, D. (2003). The impact of self-assessment on achievement: the effects of self-assessment training on performance in external examinations'. Assessment in Education, 10(2), 209-220.

Ministry of Education - MoE (1994). Ethiopian Education Sector Development Policy- ESDP-I. Addis Ababa, Ethiopia.

Nikko, D. (1995). 'Formative assessment and self-regulated learning: a model andseven principles of good feedback practice', Studies in Higher Education, 31(2).

Pelligrino, J. W., Chudowsky, N., \& Glaser, R. (Ed). (2001). Knowing what Students Know -The Science and Design of Educational Assessment. Washington, DC, National Academic Press.

Rowntree, D. (1987). Assessing Students: How shall we know them? London: Kogan Page.

Schwartz, P., \& Webb, G. (2002). Assessment: Case Studies, Experiences and Practices from Higher Education. London: Kogan Page.

Smith, G. (1996). Alternative assessments and successful school reform: Power, participation and equity: Teacher Education and School Reform. International Yearbook on teacher Education. 1996. Conference Proceedings.

Smith, R., \& Malec, F. (1995). Higher Education and Initial Teacher Training. London: Kogan Page.

Stefani, L. A. J. (1998). 'Assessment in partnership with learners'. Assessment and Evaluation in Higher Education, 23(4), 339-350.

Teshome, A. (2001). The impact of assessment on quality education. AAU: AAU Press.

Tuckman, H. (1999). Investigating formative assessment, teaching and learning in the Classroom. Buckingham: Open University Press, McGraw Hill.

Wiliam, D. (2000). Integrating summative and formative functions of assessment', keynote address to European Association for Educational Assessment. Prague: Czech Republic.

UNESCO. (2007). The Dakar framework for action: Education for all-meeting our collective commitments. World Education Forum, Dakar, Senegal, 26-28 April. Paris: UNESCO. 


\section{Turkish Abstract \\ Sürekli Değerlendirmenin Uygulandığı Doğu Etiyopya Kamu Üniversitelerinde Karşılaşılan Zorluklar}

Bu çalıșma, Doğu Etiyopya'nın seçkin Kamu Üniversitelerinde sürekli değerlendirme uygulamasını ve uygulamanın zorluklarını araştırmayı amaçlamıştır. Bu çalışmayı gerçekleştirmek için, bir popülasyonun belirli özelliklerini sistematik ve doğru bir biçimde tanımlamaya yönelik betimleyici araştırma deseni kullanılmıştır. Bulguların yorumlanmasını kolaylaştırmak için, araştırmacılar hem betimleyici hem de çıkarımcı istatistikler kullanmıştır. Son olarak, öğretim elemanlarının yalnızca öğrencilerin sonucunu değerlendirmek ve işaretlemek için değil, aynı zamanda öğrenme becerileri ve uygulamalarını geliştirmek için sürekli değerlendirme yapmaları önerilmiştir.

Anahtar Kelimeler: uygulama, zorluk, sürekli değerlendirme, değerlendirme, psikoloji bölümü, Haramaya Üniversitesi

\section{French Abstract \\ Les Mises en ouvre et les Défis d'Évaluation Continue dans les Universités publiques de l'Éthiopie Orientale}

L'étude a été visée à examiner les mises en oeuvre et les défis d'évaluation continue dans les Universités Publiques choisies de l'Éthiopie Orientale. La conception de recherche d'enquête descriptive a été employée pour effectuer cette étude parce qu'il est utilisé à décrire les caractéristiques d'une population donnée d'une façon systématique et précise. Pour rendre l'interprétation des conclusions plus faciles, les chercheurs ont utilisé statistique descriptive et déductive. Finalement, il a été recommandé que les instructeurs doivent mettre en oeuvre l'évaluation continue non seulement pour l'évaluation et l'inscription du résultat des étudiants, mais aussi pour des compétences apprenant et des pratiques.

Mots Clés: mise en oeuvre, défi, évaluation continue, évaluation, département de psychologie, Université Haramaya

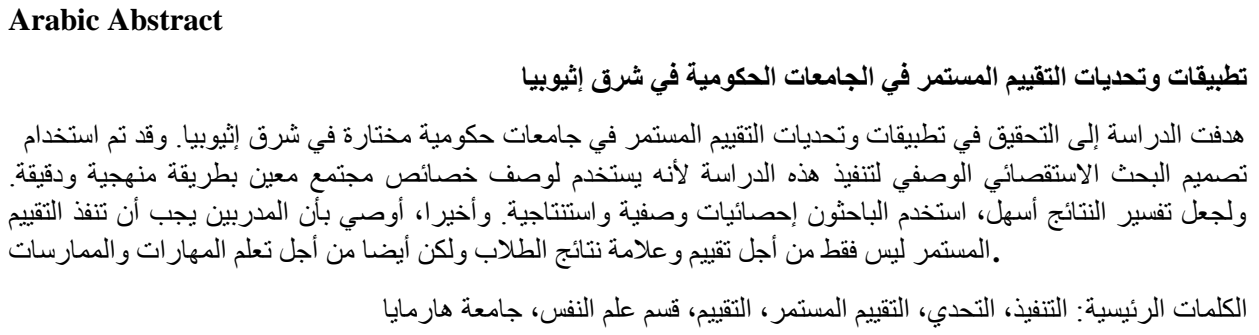




\section{German Abstract \\ Die Implementierungen und Herausforderungen der kontinuierlichen Bewertung in öffentlichen Universitäten von Ost-Äthiopien}

Die Studie zielte darauf ab, die Implementierungen und Herausforderungen der kontinuierlichen Bewertung in ausgewählten öffentlichen Universitäten von Ost-Äthiopien zu untersuchen. Beschreibende Umfrage Forschung Design wurde verwendet, um diese Studie durchzuführen, weil es verwendet wird, um die Merkmale einer bestimmten Population in einer systematischen und genauen Weise zu beschreiben. Um die Interpretation der Ergebnisse zu erleichtern, verwendeten die Forscher sowohl deskriptive als auch inferentielle Statistiken. Schließlich wurde empfohlen, dass die Instruktoren eine kontinuierliche Bewertung nicht nur zur Bewertung und Kennzeichnung des Studentenergebnisses durchführen sollten, sondern auch um Lernfähigkeiten und Praktiken zu erlernen.

Schlüsselwörter: umsetzung, herausforderung, kontinuierliche bewertung, bewertung, abteilung für psychologie, Haramaya University

\section{Malaysian Abstract \\ Pelaksanaan dan Cabaran Penilaian Berterusan di Universiti Awam Ethiopia Timur}

Kajian ini bertujuan untuk menyiasat pelaksanaan dan cabaran penilaian berterusan di Universiti Awam Timur Ethiopia yang terpilih. Reka bentuk penyelidikan tinjauan deskriptif digunakan untuk menjalankan kajian ini kerana ia digunakan untuk menggambarkan ciri-ciri populasi tertentu dalam fesyen yang sistematik dan tepat. Untuk membuat interpretasi penemuan lebih mudah, para penyelidik menggunakan kedua-dua statistik deskriptif dan inferensi. Akhir sekali, adalah disyorkan bahawa pengajar perlu melaksanakan penilaian berterusan bukan sahaja untuk menilai dan menandakan keputusan pelajar tetapi juga demi kemahiran dan amalan pembelajaran.

Kata Kunci: pelaksanaan, cabaran, penilaian berterusan, penilaian, jabatan psikologi, Universiti Haramaya

\section{Russian Abstract}

Реализации и Проблемы Непрерывной Оценки в Государственных Университетах Восточной Эфиопии

Целью исследования было изучить реализацию и задачи непрерывной оценки в отдельных государственных университетах Восточной Эфиопии. Для проведения этого исследования был использован проект описательной исследовательской съемки, поскольку он используется для систематического и точного описания характеристик данной популяции. чтобы сделать интерпретацию результатов, исследователи использовали как описательную, так и выведенный статистику. Наконец, было рекомендовано, чтобы преподаватели проводили непрерывную оценку не только ради оценки и маркировки результатов учащихся, но и для обучения навыкам и практике.

Ключевые Слова: реализация, вызов, непрерывная оценка, оценка, отдел психологии, Университет Харамаи 